This item was submitted to Loughborough's Research Repository by the author.

Items in Figshare are protected by copyright, with all rights reserved, unless otherwise indicated.

\title{
Freeform construction application research
}

PLEASE CITE THE PUBLISHED VERSION

http://dx.doi.org/10.1007/1-4020-4891-2_65

PUBLISHER

(C) Springer

VERSION

AM (Accepted Manuscript)

LICENCE

CC BY-NC-ND 4.0

REPOSITORY RECORD

Buswell, Richard A., Rupert C. Soar, Alistair G.F. Gibb, and Tony Thorpe. 2019. "Freeform Construction Application Research". figshare. https://hdl.handle.net/2134/10143. 
This item was submitted to Loughborough's Institutional Repository (https://dspace.lboro.ac.uk/) by the author and is made available under the following Creative Commons Licence conditions.

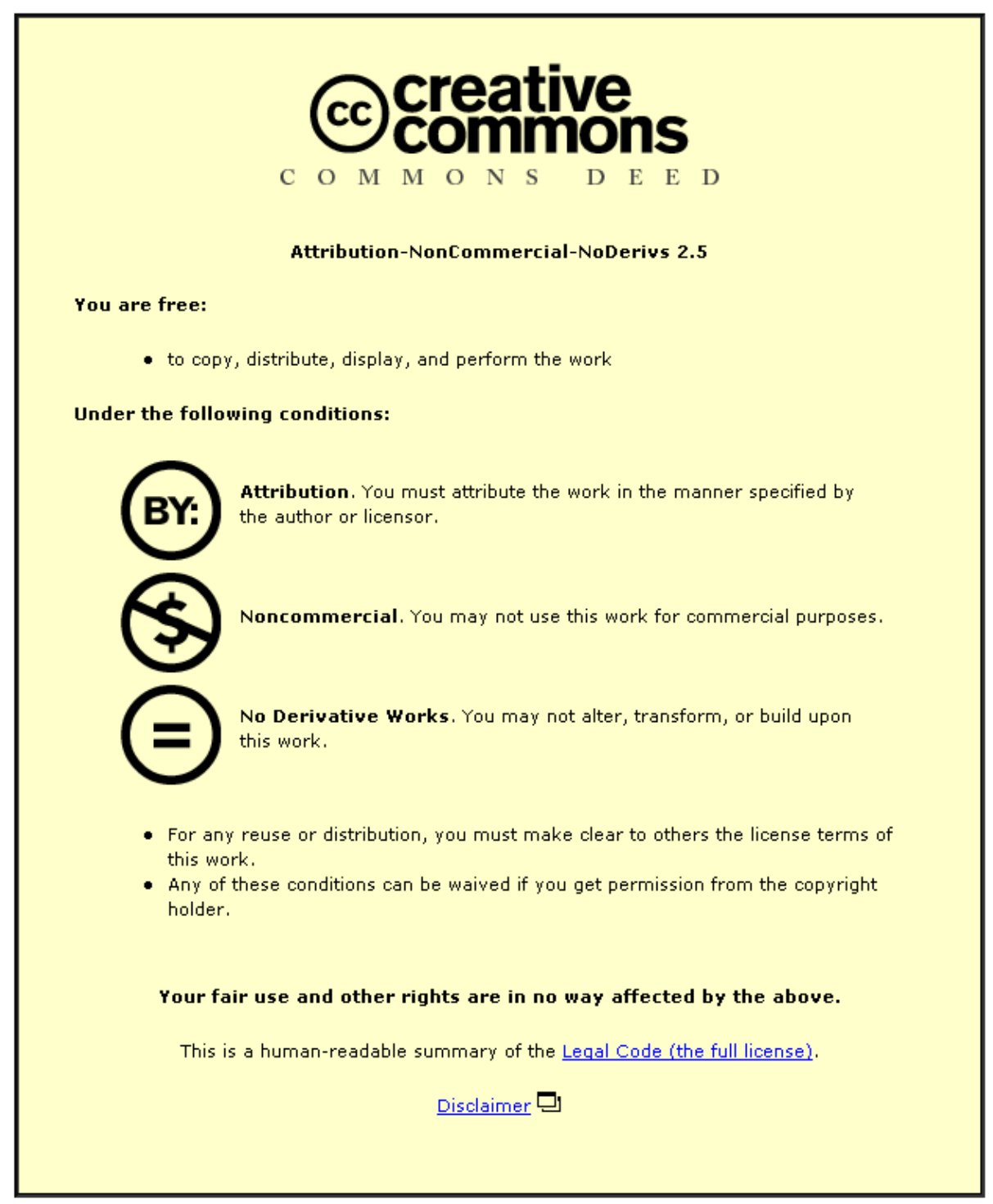

For the full text of this licence, please go to: http://creativecommons.org/licenses/by-nc-nd/2.5/ 


\title{
FREEFORM CONSTRUCTION APPLICATION RESEARCH
}

\author{
R.A. Buswell ${ }^{1}$, R.C. Soar ${ }^{1}$, A.G.F. Gibb ${ }^{2}$ and A. Thorpe $e^{2}$
}

\begin{abstract}
Abstact
The level of automation technology and processes control, within the construction sector, faces unique challenges if it is to catch up with automotive and aerospace applications. The construction industry has problems relating to health and safety, environmental legislation and traditional methods of procurement. These are compounded by diminishing skills in the labour force. One way to address these issues is by increased automation and integration of design, modelling and process control. Digital Fabrication has demonstrated the feasibility of the integration of design and component production on a large scale. Freeform Construction builds on Digital Fabrication by integrating the control of final material deposition. This paper reports on recent meetings held with industrialists to gauge their perceptions of the technology and encourage discourse to identify both applications and opportunities for the wider research community. Examples of digital fabrication in construction are discussed. Freeform Construction is defined and potential applications are presented. An example of physical model generation from construction CAD software is described.
\end{abstract}

Key Words: Construction Automation, Rapid Manufacturing, Additive Manufacturing, Freeform Construction.

\section{Introduction}

Freeform Construction is an initiative that considers the benefits of automated layer based, additive production methods for construction. These methods can be applied, conceptually at least, at any scale from desktop model to full scale building construction. This paper describes results from a recently completed project that investigated the potentials for such applications in conjunction with industry.

\section{Issues for the Construction Industry}

The construction industry has yet to realise the benefit technological step changes in process can bring, placing it behind industries such as aerospace, automotive and ship building. For most applications, the fundamental principles of construction have changed little for hundreds of years; material placement is still primarily a manual operation. Often the legal framework that enable the business of construction acts as a disincentive to trial new approaches. Competition for projects concentrate on first cost. The industry is conservative and innovations tend to be through incremental change. There is a growing skills shortage in the UK compounded by an aging population. Construction remains a hazardous environment. The industry is likely to face increasing pressures from developing environmental legislation, waste management, and energy conservation measures (Guthrie et al. 1999).

The UK government has been addressing these issues through a succession of initiatives, prompted by the Latham and Egan Reports (Egan 1998, Latham 1994) and ultimately by 'Constructing Excellence.'

\footnotetext{
${ }^{1}$ Richard Buswell and Rupert Soar: Wolfson School, Loughborough University, UK.

Corresponding Author: r.a.buswell@lboro.ac.uk

${ }^{2}$ Alistair Gibb and Tony Thorpe: Civil and Building Engineering, Loughborough University, UK.
} 
The drive is towards leaner, better Modern Methods of Construction. There is, however a need for a more radically different solutions. As human endeavour pushes further forward, construction will need to be able to respond to unique challenges in aggressive environments such as the North pole, desert, chemical contamination and off-world. The industry will need to respond to environmental issues with new materials and new solutions for buildings at 'end of life'.

\section{Additive Processes}

Construction can be described as a mixture of additive process and assembly of components. A big question is whether the layer by layer additive processes found in Rapid Prototyping and Rapid Manufacturing can inspire processes for larger scale automation useful to construction.

Traditionally, the realisation of a component design was costly because of the involvement of man hours for the production of a few bespoke parts. The development of computer aided modelling has allowed designs to be developed faster, particularly when combined with simulation and modelling software. These computer representations of solid 3D objects can be used to control additive manufacturing machines, producing a physical component. These machines reconstruct the 3D object by sequentially bonding '2D' layers of material. The technology's impact to existing manufacturing has been in the form of waste reduction when compared to machining processes and the elimination of tooling when compared to moulding or casting processes. A useful by-product of this approach is almost unlimited geometrical freedom and that moving parts can be constructed in a single build, negating the need for assembly. Additive manufacturing processes are seeding a revolution in customised, end-use parts, adding value to parts (Wohlers 2004).

Additive manufacturing technologies have been used for construction applications, but have been largely restricted to concept modelling in architecture (Kalay, Skibniewski 2002). There are two notable exceptions: Pegna (1997) considered a layer deposition method suitable for traditional construction materials; Contour Crafting is the first automated layer manufacturing process that has been demonstrated to have the potential for generating large structures directly from digital data (Khoshnevis 2002).

\section{Constructing from Digital Models}

The ability to use solid 3D CAD models, with computer based analysis tools is generating impressive freeform architecture (Kolarevic 2003, Stacey, Beesley \& Hui 2004). In recent years there have a number of buildings constructed using large scale manufacturing methods to create structural components that are assembled on site. Gehry's Zollhoff Towers is one.

Today Construction is using CAD/CAM to liberate architectural possibilities. We can control the shape of construction components directly from the digital design model. The next technological step is to control the deposition of the construction material directly from the building model. This is Freeform Construction.

Additive process can be applied at various scales from hand held items to whole buildings. As the application scale increases, it may become possible to manufacture modular, or volumetric components. Systems integration is a benefit at this scale. Services can be assembled inside the structure as it is built. Although building objects using additive manufacturing processes at this scale does not exist, processes such as 3D printing, are potentially scalable. The benefits of systems integration and structural optimisation are maximised if the building as a whole are produced by a machine. 


\section{Identifying Freeform Construction Applications}

To generate applications of Freeform Construction technology that are grounded by industry, 17 practitioners and 6 academics, representing 13 organisations were canvassed for ideas during the course of a one day workshop. Engineers, architects, construction managers, academia, CAD software houses and construction innovations developers were represented. Two groups of 7-8 were selected such that each group was reasonably diverse in terms of the professions represented. In each of the groups, each person was asked to provide answers to the question:

\section{'If you could have a 'freeform machine' today what would you use it for?'}

Table 1 rationalises the responses. The discussion fell into broad categories that reflected the elements of a building and construction. Six technology categories also emerged. Potential applications tended to fall into those that can be delivered through improving computing technology and those that require a physical process and/or materials. Of those, some applications reflected what can be achieved through Rapid Manufacturing and CAD/CAM technologies today. Examples of others reflected what is being achieved in high end architecture though digital fabrication. More far reaching applications tended to fall into three further categories: new specialist processes that provide a solution for use in a conventional construction environment; those that would be particularly suited to off site fabrication using new technologies; and those applications that are only conceivable when new technologies are applied to the construction of the whole structure.

The sense of the group who contributed to Table 1 was that Freeform approaches could help in the manufacture of complex forms and in component and systems integration. One major issue identified, was that of responsibility. Where integrated components have two or more functions, i.e. a wall with heating water transport and electrical distribution, then who takes the responsibility for the design? If digital design information is used directly by the 'contractor' via a digitally controlled process, who is responsible for the construction; the designer, the contractor or those who built the machine?

The study demonstrated that there is a desire to improve how construction is procured. Technology can play a significant role and it is likely that the viability of new processes will be driven by specialist application. Major issues for large scale Freeform Construction, however, will be in proving the viability of the technology, establishing design process, contract requirements and supply chains to enable it.

\section{An Example of Model Production}

Table 1 identifies the application of model production. This is useful for visualisation, communication and conflict resolution. The application of architectural models is not new and Rapid Prototyping is a proven technology in this respect. For wide spread application in the industry, across architecture and engineering, the transition of information from designer and CAD to Prototyping machine must be simple. This initial investigation to identified some of the issues with using a model from a construction oriented CAD package to produce a physical model using a Rapid Prototyping process.

Virtually all Rapid Prototyping machines accept a data format called STL. This data format describes the object to be built using a single tessellated surface where the inside and outside faces of the surface is defined. What is 'inside' is deemed to be solid. This data model is 'sliced' into layers. The machine interprets which part of each layer is solid and which is not. The information controls the sequential reconstruction of the object in the physical world, a layer at a time, ground up. There is a continual cycle of operations, applying a new layer of material across the build platform and selectively turning the 'internal' parts of that layer solid using an activation process. In the case of the Selective Laser 
Table 1: Classified Applications for Freeform Construction.

\begin{tabular}{|c|c|c|c|c|c|c|}
\hline $\begin{array}{c}\text { State of Technology } \\
\text { Development }\end{array}$ & $\begin{array}{c}\text { Ongoing } \\
\text { Improvements to } \\
\text { Existing Technology }\end{array}$ & $\begin{array}{l}\text { Widespread Use } \\
\text { Today in } \\
\text { Manufacturing }\end{array}$ & $\begin{array}{c}\text { State of the Art } \\
\text { Today on High End, } \\
\text { Architectural } \\
\text { Projects }\end{array}$ & $\begin{array}{c}\text { Probable First Line } \\
\text { of Technology } \\
\text { Introduction }\end{array}$ & $\begin{array}{l}\text { Probable First- } \\
\text { Second line of } \\
\text { Technology } \\
\text { Introduction }\end{array}$ & $\begin{array}{c}\text { More Speculative } \\
\text { Technologies }\end{array}$ \\
\hline Building Element & $\begin{array}{l}\text { Modelling, Design } \\
\text { \& Computational } \\
\text { Analysis Tools } \\
\end{array}$ & $\begin{array}{l}\text { Current Rapid and } \\
\text { CAD/CAM } \\
\text { Manufacturing }\end{array}$ & $\begin{array}{l}\text { Current Digital } \\
\text { Fabrication in } \\
\text { Construction }\end{array}$ & $\begin{array}{l}\text { Mix of Traditional } \\
\text { \& Hybrid } \\
\text { Technologies }\end{array}$ & $\begin{array}{l}\text { Technologies For } \\
\text { Off Site } \\
\text { Applications }\end{array}$ & $\begin{array}{l}\text { Large Scale Whole } \\
\text { Structure, On Site } \\
\text { Approaches }\end{array}$ \\
\hline $\begin{array}{l}\text { Design + } \\
\text { Communication }\end{array}$ & $\begin{array}{l}\text { Greater degree of } \\
\text { client interaction in } \\
\text { design of } \\
\text { architectural space, } \\
\text { i.e. hands on } \\
\text { interaction with the } \\
\text { model - a 'what you } \\
\text { see is what you get' } \\
\text { approach to } \\
\text { construction. }\end{array}$ & & $\begin{array}{l}\text { Realisation of non- } \\
\text { linear surface forms } \\
\text { for buildings. }\end{array}$ & & & $\begin{array}{l}\text { Generate new } \\
\text { architectural } \\
\text { possibilities in addition } \\
\text { to improving } \\
\text { personalised/ergonomic } \\
\text { design - no more } \\
\text { straight lines and } \\
\text { corners. }\end{array}$ \\
\hline Structure & $\begin{array}{l}\text { Greater degree of } \\
\text { numerical } \\
\text { optimisation - } \\
\text { minimisation of } \\
\text { building material } \\
\text { and improved } \\
\text { building } \\
\text { performance. }\end{array}$ & $\begin{array}{l}\text { Contour crafting } \\
\text { demonstrated to be } \\
\text { capable of building } \\
\text { large wall structures } \\
\text { using CAD/CAM } \\
\text { technology. }\end{array}$ & $\begin{array}{l}\text { Realisation of } \\
\text { support systems for } \\
\text { highly curved } \\
\text { surfaces. }\end{array}$ & & & $\begin{array}{l}\text { Possibility of } \\
\text { tension/compression } \\
\text { structures. }\end{array}$ \\
\hline Roofs \& Canopies & $\begin{array}{l}\text { Improved design for } \\
\text { thermal insulation. }\end{array}$ & & $\begin{array}{l}\text { Shop drawings } \\
\text { derived from 3D } \\
\text { digital models. }\end{array}$ & & & $\begin{array}{l}\text { Possibility of } \\
\text { monolithic curved } \\
\text { enclosures. }\end{array}$ \\
\hline $\begin{array}{l}\text { Floors, Ceilings and } \\
\text { Walls }\end{array}$ & $\begin{array}{l}\text { Improved design for } \\
\text { thermal insulation }\end{array}$ & & & & $\begin{array}{l}\text { Integrating service } \\
\text { systems into } \\
\text { partitions and } \\
\text { volumetric } \\
\text { assemblies. }\end{array}$ & $\begin{array}{l}\text { Integrating service } \\
\text { systems into building } \\
\text { fabric. }\end{array}$ \\
\hline
\end{tabular}


Table 1 Continued: Classified Applications for Freeform Construction.

\begin{tabular}{|c|c|c|c|c|c|c|}
\hline Building Element & $\begin{array}{l}\text { Modelling, Design } \\
\text { \& Computational } \\
\text { Analysis Tools }\end{array}$ & $\begin{array}{l}\text { Current Rapid and } \\
\text { CAD/CAM } \\
\text { Manufacturing }\end{array}$ & $\begin{array}{l}\text { Current Digital } \\
\text { Fabrication in } \\
\text { Construction } \\
\end{array}$ & $\begin{array}{l}\text { Mix of Traditional } \\
\text { \& Hybrid } \\
\text { Technologies }\end{array}$ & $\begin{array}{l}\text { Technologies For } \\
\text { Off Site } \\
\text { Applications }\end{array}$ & $\begin{array}{l}\text { Large Scale Whole } \\
\text { Structure, On Site } \\
\text { Approaches }\end{array}$ \\
\hline $\begin{array}{l}\text { Surfaces, Finishes } \\
\text { \& Decoration }\end{array}$ & $\begin{array}{l}\text { Design possibilities } \\
\text { for integrated } \\
\text { storage, bespoke } \\
\text { sanitary ware. }\end{array}$ & $\begin{array}{l}\text { Reproduction of } \\
\text { heritage architecture. }\end{array}$ & $\begin{array}{l}\text { External surfaces - } \\
\text { shop drawings } \\
\text { derived from 3D } \\
\text { digital models. }\end{array}$ & $\begin{array}{l}\text { Embedding control } \\
\text { systems in surfaces. }\end{array}$ & $\begin{array}{l}\text { Possibility of } \\
\text { seamless finishes. }\end{array}$ & $\begin{array}{l}\text { Possibility of joint-less } \\
\text { construction, precise } \\
\text { surface property } \\
\text { control. And greater } \\
\text { variety of surface } \\
\text { finishes. }\end{array}$ \\
\hline Openings & & & & & $\begin{array}{l}\text { Possibility of } \\
\text { structural glazing } \\
\text { systems. }\end{array}$ & $\begin{array}{l}\text { Possibility of structural } \\
\text { glazing systems. }\end{array}$ \\
\hline $\begin{array}{l}\text { Mechanical \& } \\
\text { Electrical Systems }\end{array}$ & $\begin{array}{l}\text { Increased building } \\
\text { modelling could } \\
\text { generate optimal } \\
\text { routes - minimising } \\
\text { material use and in } \\
\text { use losses i.e. } \\
\text { improved efficiency. }\end{array}$ & & & $\begin{array}{l}\text { Possibility of } \\
\text { generating } \\
\text { space/weight } \\
\text { optimised service } \\
\text { models for faster } \\
\text { services installation } \\
\text { in traditional } \\
\text { construction. }\end{array}$ & $\begin{array}{l}\text { Systems integration } \\
\text { with fabric. }\end{array}$ & $\begin{array}{l}\text { Systems integration } \\
\text { with fabric. In addition, } \\
\text { the model used to } \\
\text { generate the building is } \\
\text { the 'as built' } \\
\text { information. }\end{array}$ \\
\hline $\begin{array}{l}\text { Fixings, Flashings } \\
\text { and Junctions }\end{array}$ & & $\begin{array}{l}\text { Creation of bespoke } \\
\text { façade system } \\
\text { fixtures and fittings. }\end{array}$ & & $\begin{array}{l}\text { Improved weather } \\
\text { protection at service } \\
\text { penetrations. }\end{array}$ & & $\begin{array}{l}\text { Elimination of } \\
\text { troublesome system } \\
\text { interfaces. }\end{array}$ \\
\hline Temporary Works & & & $\begin{array}{l}\text { Examples of } \\
\text { automated on site } \\
\text { 'factory' } \\
\text { environments that } \\
\text { enclose the entire } \\
\text { building while each } \\
\text { floor is } \\
\text { 'manufactured'. } \\
\\
\text { Generating } \\
\text { moulds/formers for } \\
\text { concrete works. } \\
\end{array}$ & $\begin{array}{l}\text { Forming water tight } \\
\text { plant-rooms for } \\
\text { early start on } \mathrm{M}+\mathrm{E} \\
\text { works. }\end{array}$ & & \\
\hline
\end{tabular}



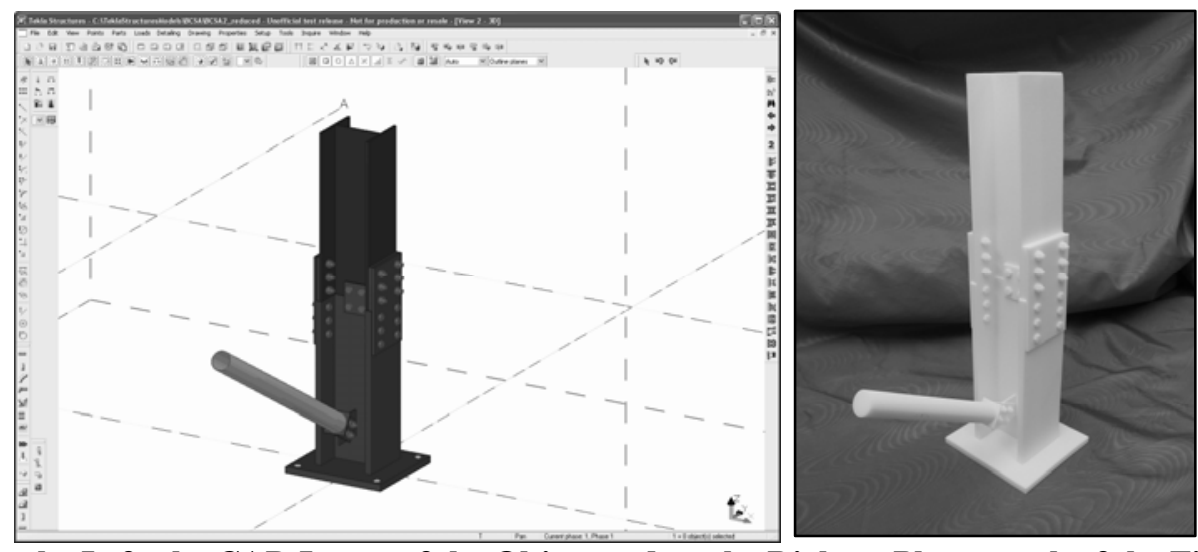

Figure 2: On the Left, the CAD Image of the Object and on the Right, a Photograph of the Finished Item.

Sintering, the solid parts of each layer of powdered material are melted, subsequently cooling and solidifying.

Where solid 3D CAD software is employed, conversion of digital model information to STL format suitable for Rapid Prototyping machines can be relatively trivial. There are two issues that are important for model production of building components. Although solid modelling is becoming more widely used, a great deal of design information is detailed in 2D CAD systems or are rendered 3D images using surface modelling. It is generally difficult, and for complicated systems practically impossible, to convert these models into good ${ }^{3}$ STL files. The machine must be told what is and isn't solid and hence must have objects with perfectly joined edges, clearly defining volume. For example, it is clear to us that a pool ball is solid, but STL data would describe it as an infinitely thin surface that has a certain volume inside. If there is a hole in that surface, you can't define what is inside and what is out and hence, what is solid. Problems like this will cause a 'build' to fail. Surface modellers and 2D CAD software are not designed to describe volume and so can't be used to generate an accurate description of a surface that will instruct a machine to make a physical object.

The second issue for construction is that assemblies of components can be problematic. Construction system designs generally describe an assembly of individual components; steel frame systems are a good example. There are construction orientated CAD systems that use solid modelling, Tekla Structures is one example (Tekla 2005). This system models every component down to the nuts, bolts and washers and hence a model of a whole system, is described as an assembly of solid objects. If a model of the complete system is required, the data must be converted to one surface describing a single object. The issue is how to combine multiple objects in the assembly so that the desired model is described as one homogenous unit.

The left hand picture in Figure 2 details the CAD image of an example steel section modelled using Tekla Structures. This software models each component as a solid object but it does not have an integrated STL conversion function. To generate the STL file, the data was loaded into the solid modeller, Rhino 3D (Rhinoceros 2005), using a file format common to both (DXF). Using the automated functions within Rhino, the STL file generated was made up of many surfaces. Each surface defining the individual objects in the design. A model of the entire assembly was required. Using Magics, an STL file editing software package (Materialise 2006), each object surface was combined using an operation which merges one object with another, resulting in a single surface. The dimensions of the object were scaled to suit the size of the Rapid Prototyping machine and then built in nylon using a Selective Laser Sintering process. The final part is depicted on the right hand side of Figure 2.

\footnotetext{
${ }^{3}$ i.e. STL files that will procure a successful build on a Rapid Prototyping machine.
} 
At present, if a model of a building, component or subassembly is required, it is likely that separate operations will be required to encode the design into solid modelling software in order to produce a STL file that is capable of instructing a machine to build the physical object. If an assembly of solid objects are used to describe the item to be built, additional operations will be required to generate a single object in STL. As software develops, it is likely that the latter will be achievable through prescribed software functions. If solid modelling becomes the standard way of describing building information in the future, the former issue will become obsolete.

\section{Conclusions}

There are many examples in construction where new technologies are moving away from the use of traditional methods of building procurement to those that can be designed and fabricated digitally. It is likely that this trend will grow. To enable the full benefits of construction automation, radically new process are required. The freeform approach is well placed to contribute. By engaging with industry, potential applications have been identified. These range from near market solutions to some that will take years, even decades to be exploited commercially.

Generally freeform methods can find ready application in geometrically complex building components or the integration of systems. Specialist applications seemed to be most probable locations for early development. One hurdle to overcome is that of information handling. Solid modelling as a real tool for construction is in it's infancy when compared to ship building or aerospace engineering. An additional factor is that to be successful, the digital building model information needs to be readily used by all members of the supply chain. This will mean greater use of CAD/CAM manufacturing technologies by suppliers. The modelling example, although fairly trivial, does demonstrate that there is a little way to go before the use and exchange of construction information with Rapid Prototyping type processes becomes trivial. Such issues will be exacerbated when generating full scale structures.

\section{Acknowledgements}

The Authors would like to thank the EPSRC for the funding of this project through the IMCRC at Loughborough University. We would like to thank BPB plc and Z Corporation for their support and in particular the contributions of Keith Humphrey and Tom Clay. We would also like to thank Clive Robinson and Tekla for the modelling example.

\section{References}

Egan, J. 1998, Rethinking Construction, Department of the Environment, London.

Guthrie, P., Coventry, S., Woolveridge, C., Hillier, S. \& Collins, R. 1999, The reclaimed and recycled construction materials handbook CIRIA, London.

Kalay, Y.E. \& Skibniewski, M.J. 2002, "Special Issue: Rapid Prototyping", Automation in Construction, vol. 11, no. 3.

Khoshnevis, B. 2002, "Automated Construction by Contour Crafting â€“ Related Robotics and Information Sciences", Automation in Construction Special Issue: The best of ISARC 2002, vol. 13, no. 1, pp. 2-9. 
Kolarevic, B. 2003, Architecture in the Digital Age: Design and Manufacturing, New York \& London: Spon Press - Taylor \& Francis Group.

Latham, M. 1994, Constructing the Team, HMSO, London.

Materialise 2006, 1/9/2006-last update, Magics [Homepage of Materialise], [Online]. Available: http://www.materialise.com/magics-rp/main_ENG.html [2006, 1/9] .

Pegna, J. 1997, "Exploratory investigation of solid freeform construction", Automation in Construction, vol. 5, no. 5, pp. 427-437.

Rhinoceros 2005, , Rhinoceros [Homepage of Rhinoceros], [Online]. Available: www.Rhino3d.com $[2005,12 / 10]$.

Stacey, M., Beesley, P. \& Hui, V. 2004, Digital Fabricators, 1st edn, University of Waterloo School of Architecture Press, Waterloo, Canada.

Tekla 2005, , Tekla Corporation [Homepage of Tekla], [Online]. Available: www.tekla.com [2005, $12 / 10]$.

Wohlers, T. 2004, Rapid Prototyping, Tooling \& Manufacturing: State of the Industry, Wohlers Associates, Colorado, USA. 